technique of television offers an opportunity of controlling contrast. Details of the original picture and the reproduced picture at one stage are both held in terms of electrical energy and can be manipulated. With coloured light our problem is not merely to measure colour, but also to measure and specify colour and colour-rendering properties. The colour of light can readily be specified on the I.C.I. trichromatic system, and a rapid technique for indicating the colour of a light source directly on this system has recently been evolved. No standard has yet, however, been set up for the colour-rendering properties of light.

\section{Devil's Dyke, Wheathampstead}

THE presentation to the public of land at Wheathampstead, which has been made by Lord Brocket, chairman of the Hertfordshire Society of the Council for the Preservation of Rural England, as a personal gift commemorating the coronation of King George and Queen Elizabeth, preserves as an open space in perpetuity a site which, as has been shown by the excavations of Dr. R. E. Mortimer Wheeler, is of outstanding archæological and historical significance. For in addition to the four acres of the prehistoric earthwork, known locally as the Devil's Dyke, as Lord Brocket announced in handing over the 999 years' lease to the Wheathampstead Parish Council on October 23, the adjacent area of one hundred acres will also be preserved as an open space under an arrangement he proposes to make with the Hertfordshire County Council and the National Trust. It was here, Dr. Wheeler has shown, that there was situated the fortress, or oppidum, of more than a hundred acres in extent, the largest and strongest in Britain as yet known in its period, which was held by the Belgic tribes who had settled in Britain not long before, and of which the capture as the headquarters of the British forces was the climax of the campaign. in the second of Cæsar's invasions of Britain; while almost immediately after that event, it would seem, it became the parent city of the British stronghold, also excavated by Dr. Wheeler, at Verulamium, which preceded the Roman occupation. The importance of the site for the history of pre-Roman Britain lays a debt of gratitude to the donor for his gift upon circles far wider than those immediately affected by its preservation of local amenities in the future development of the district.

\section{Archæological Evidence and 'Development'}

IT is unfortunately only too true that in many instances no private benefactor has been available, nor has public interest been sufficiently strong, to save relics of the past thought by many worthy of preservation, as the Wheathampstead site will be preserved. At the same time, land development and public improvement have not invariably run entirely counter to the interests of the archæologist. Not only have they brought to light antiquities of which the existence under the surface of the ground was unsuspected, but also on occasion they have made possible archæological investigations which other- wise it would probably have been impossible to undertake. The exploration of so large a site as that recently excavated at Colchester would have been difficult, if not definitely impossible, had it not been carried out in conjunction with the making of the new road. It is, however, not only the destruction of antiquities that is to be feared. Among other dangers there is the possibility of serious confusion of evidence which may follow the removal of archæological material from one area to another. An instance in point is mentioned by $\mathrm{Mr}$. S. E. Winbolt in a communication to The Times of October 22, in which he records the discovery of a Roman house in the course of widening a road at Wiggonholt near Pulborough. The soil from this site is being transported by lorry to Pulborough Causeway, two and a half miles away. The discovery was made on the site of cottages called Lickfold (cabbage patch); and in the soil have been found fragments of Roman pottery, Samian and Castor, the foot-ring of a large Samian bowl, and a complete upperstone of a disk quern, fourteen inches in diameter, as well as a mortarium of first- to second-century type. $\mathrm{Mr}$. Winbolt points out that future excavation on the Causeway, which is being widened on both sides, might bring to light Roman material from the Wiggonholt site, which would lead to quite erroneous conclusions as to the relation of the Causeway to Stane Street. Local societies might well be at pains to record any such shifting of material from sites within their respective areas.

\section{British Museum (Natural History): Acquisitions}

THE most important recent zoological accession to the Zoological Department of the British Museum (Natural History) is perhaps a collection of mammals and birds made by Messrs. Charles and Edward G. Bird in the Mygybukta region of North East Green. land. The collection is of special interest since it contains examples in breeding plumage and chicks of birds well known in the British Isles in winter, such as the knot, sanderling, turnstone and brent goose. There are also specimens of the ptarmigan in breeding plumage, as well as young birds and small ducklings of the king eider - a rare visitor to Britain. Among the mammals are specimens of the lemming, skulls and skeletons of aretic foxes, and various seals. Another important acquisition to the Department is the mounted head of a chobe situtunga (Limnotragus spekei selousi) presented by Major Henry Abel Smith. This rare antelope is known only from about a dozen specimens and enjoys a distribution to the south of the Zambesi between the Chobe Swamps and Lake Ngami in Bechuanaland. Among the accessions to the Department of Entomology is the very valuable collection of butterflies formed by Major P. P. Graves in the Near East, particularly in Palestine, Asia Minor, Syria, the southern Balkans and Greece. This collection is made up of more than 9,000 specimens, and is particularly rich in material from historic localities which were extensively worked by German and Austrian collectors in the middle of the last century. 